\title{
Editorial
}

\section{Ensino de Paisagem e Educação Ambiental e Formação em Ciências e Matemática}

O número 99 caracteriza-se por apresentar um conjunto de artigos temáticos.

O primeiro tema, expresso em cinco artigos de autores espanhóis, aborda o ensino do conceito de paisagem e educação ambiental, que é problematizado no texto de apresentação escrito pelo doutor Alfonso García De La Vega, da Universidad Autónoma de Madrid, organizador dessa demanda específica. No texto "El Paisaje y la Educación Ambiental", o autor evidencia a abordagem desde uma perspectiva multidisciplinar, com especial atenção ao enfoque geográfico. Aponta, ainda, que a Geografia tem oferecido uma visão global da relação entre o âmbito natural e as intervenções humanas, cujas transformações geram paisagens culturais singulares.

Outro tema agrega os artigos sobre a formação docente em Ciências e Matemática, submetidos espontaneamente por autores brasileiros e portugueses.

No artigo "AS MARCAS SOCIAIS DEIXADAS PELAS ESCOLAS EM NOSSOS PROFESSORES DE CIÊNCIAS: A QUESTÃO DA VIOLÊNCIA SIMBÓLICA", Graciella Watanabe e Ivã Gurgel propõem que elas são deixadas na memória e evocadas em situações cotidianas, nas quais se apresentam na forma do habitus em diversas reações que são convocadas pelo campo profissional. Esse trabalho pretende recuperar os aspectos sociais que marcaram um conjunto de 136 professores de Ciências da Escola Básica (fundamental e média) em sua trajetória histórica e as influencias na sua atuação profissional.

Maria Eduarda Roque Ferreira, Carla Cepa, Rosa Tracana e Carlos Francisco Reis, no texto "Reciclar recordações com as ciências - percursos de aprendizagem em contexto de jardim de infância”, partiram do pressuposto de que a educação se baseia em premissas sociais, culturais, individuais e coletivas. 
Neste contexto, foi desenvolvida, com um grupo de crianças da educação pré-escolar, uma experiência pedagógico-didática intitulada Reciclar Recordações - A Magia das Ciências, que foi trabalhada de modo interdisciplinar e operacionalizada pormeio da realização de atividades práticas, tendo por enfoque a triangulação ciência-criança-meio sociocultural.

Andrea Inês Goldschmidt, Nathália Vieira Silva, Jenyffer Soares Estival Murça e Brucce Sanderson Prado de Freitas, no artigo "O que é ciência? Concepções de licenciandos em Ciências Biológicas e Química”, procuraram identificar e analisar as concepções sobre natureza da Ciência entre acadêmicos dos cursos de Graduação (Licenciatura) em Ciências Biológicas e Química da Universidade Federal de Goiás e a partir desta analisar os contextos epistemológicos que a cercam.

Por fim, Mazonilde Dalvina Costa Souza, Márcia Jussara Hepp Rehfeldt e Ieda Maria Giongo, no artigo "A Aprendizagem da geometria por meio de obras cubistas no $5^{\circ}$ Ano da Educação de Jovens e Adultos - EJA", apresentam o resultado da pesquisa desenvolvida no Mestrado Profissional em Ensino de Ciências Exatas do Centro Universitário Univates, que teve como objetivo identificar de que forma o estudo do movimento cubista pode contribuir para a aprendizagem significativa da Geometria no $5^{\circ}$ ano da Educação de Jovens e Adultos - EJA - na Escola Municipal Maria Gertrudes Mota de Lima. Tal pesquisa fundamentou-se na teoria de aprendizagem de David Ausubel e nos documentos que regem a Educação de Jovens e Adultos. Foram consultadas obras, como Ausubel (2003), Moreira (2011a, b), Fainguelernt e Nunes (2006).

Recomendamos a leitura dos textos, visto que propõem novas reflexões sobre temas tão caros à educação e ao ensino.

\author{
Maria Cristina Pansera-de-Araújo \\ Maria Simone Vione Schwengber \\ Celso José Martinazzo \\ Solange Castro Schorn
}

